\title{
Accumulation of heavy metals in needles and bark of Pinus species
}

\author{
Agnieszka Parzych $\bowtie$, Sergej Mochnacký2, Zbigniew Sobisz ${ }^{1}$, Natalia Kurhaluk ${ }^{1}$, \\ Nora Polláková \\ 1 Pomeranian University in Słupsk, Institute of Biology and Environmental Protection, Arciszewskiego 22b, \\ 76-200 Słupsk, Poland, e-mail: agnieszka.parzych@apsl.edu.pl \\ ${ }^{2}$ Universitet of P.J. Šafárik in Košice, Botanical Garden, Mánesova 23, 04352 Košice, Slovak Republic \\ ${ }^{3}$ Slovak University of Agriculture in Nitra, Department of Soil Science and Geology, Tr. A. Hlinku 2, 94976 Nitra, \\ Slovak Republic
}

\section{Abstract}

During the research, cumulative properties of conifer needles $P$. armandii, P. banksiana, P. mugo, P. nigra, P. sylvestris and $P$. wallichiana in reference to $\mathrm{Cu}, \mathrm{Ni}, \mathrm{Mn}, \mathrm{Fe}, \mathrm{Zn}$ and $\mathrm{Cd}$ were analysed, and the factors which have an impact on the chemical composition of the bark of those species were identified. During the study, the age of needles and the content of the examined components in soil was taken into consideration. The content of metals in the needles varied, depending on a species and the age of the coniferous needles. In most cases, a higher level of content of those metals was determined in 2 years old needles, except for $\mathrm{Cu}$ and $\mathrm{Zn}(P$. banksiana) as well as $\mathrm{Zn}(P$. nigra), in which case, higher concentration of metals in 1 year old needles was determined. The obtained results indicate that the heavy metals' concentration in the samples of needles was relatively low, except for $\mathrm{Ni}$ (P. armandii, P. sylvestris, $P$. wallchiana) and Cd (P. armandii, P. banksiana), which showed higher levels. Among the examined elements, Mn was accumulated in the largest volume in the needles of $P$. banksiana, $\mathrm{Fe}$ and $\mathrm{Cu}$ in the needles of $P$. wallchiana, $\mathrm{Ni}$ in the needles of $P$. sylvestris, $\mathrm{Zn}$ in the needles of $P$. nigra and $\mathrm{Cd}$ in the needles of $P$. armandii. The bark samples represented a clearly acidic reaction, with $\mathrm{pH}$ levels from 3.7 (P. sylvestris) to 4.9 (P. armandii). The highest quantities of $\mathrm{Mn}, \mathrm{Fe}, \mathrm{Cu}$ and $\mathrm{Cd}$ were accumulated by the bark of $P$. armandii, $\mathrm{Ni}$ in the bark of $P$. sylvestris and $\mathrm{Cu}$ in the bark of $P$. mugo.

\section{KEY WORDS}

heavy metals, needles, bark, Pinus species

\section{INTRODUCTION}

The genus Pinus is one of the most widely spread in the northern hemisphere. Its species appear both in natural forests and in many botanical gardens. There are
115 known species of trees and bushes from the Pinus genus all over the world. For many years, these species have been the object of scientific research as to morphological differences (Christensen and Dar 1997), survival rate of the plovers during the forest fires (Reyes 
and Casal 2006), nutritional requirements (Parzych and Sobisz 2012), production and use of timber (Espelta et al. 2003), quantity and quality of the organic litterfall as a source of nutritional components (Astel et al. 2009), impact of the tree crowns on the properties of soil (Polláková et al. 2015), as well as monitoring research. In Poland and in many European countries, 1 year old needles and 2 years old needles of $P$. sylvestris and $P$. nigra as well as their bark are used for evaluation of the level of air pollution (Lamppu and Huttunen 2002; Yilmaz and Zengin 2003; Świercz 2006; Chrzan 2013; Parzych and Jonczak 2013, 2014). Tree needles absorb a series of chemical components that are necessary for supporting the vital processes, from soil and air (Migaszewski 1997). The intake of nutritional components by trees is regulated by metabolic processes. For adequate growth and development, in addition to micro-components, trees need adequate quantity of micro-components; this role is played to a large extent by heavy metals. However, excessive concentration of these elements in the environment is undesirable and harmful for most trees. As per Augusto et al. (2002), the species of coniferous trees absorb (about 35\%) more components than leafy trees ( $25 \%$ ) from the air due to a larger surface of the needles. The chemical composition of the needles is characterized by a specific variability resulting from the age of needles, a natural fertility of the habitat and the factors conditioning the intake of soil components. The bark of trees depending on the structure and porosity connected therewith, stops dusts and aerosols in the quantity proportional to its surface (Chrzan 2013). Pinus nigra, in comparison to other species of coniferous trees, shows high tolerance for changes of $\mathrm{pH}$ of the soil (Arsova 1999), while Pinus sylvestris to diversified abundance and moisture of the soil (Parzych and Jonczak 2013). Additionally, the artificial planting of some species of Pinus is practiced more often in order to limit erosion of the soil (Pusz et al. 2015), reconstruction of forests after fire (Espelta et al. 2003) and in order to improve the quality of degraded soils (Wójcik and Krzaklewski 2009).

The aim of this research was to compare the accumulative properties of needles of Pinus armandii Franch., Pinus banksiana Lamb., Pinus mugo Turra, Pinus nigra J.F. Arn., Pinus sylvestris L. and Pinus wallichiana A.B. Jacks. in relation to $\mathrm{Cu}, \mathrm{Ni}, \mathrm{Mn}, \mathrm{Fe}, \mathrm{Zn}$ and $\mathrm{Cd}$ and to identify the factors shaping the chemical composition of the bark of such species. In the research, the age of needles and the content of examined components in the soil were taken into account.

\section{MATERIALS AND METHODS}

\section{Research area}

The research was conducted within the area of the forest at the University botanic garden $\left(48^{\circ} 45^{\prime} \mathrm{N}, 21^{\circ} 19^{\prime} \mathrm{E}\right)$ in Košice (Slovakia) in the summer season in 2015. The garden was established in 1950 and at present its area is 30 ha. It is situated at an altitude of 218 to $370 \mathrm{~m}$ a.s.1. From the northern side, it is surrounded by natural forests. The vital part of the Park area (24 ha) is covered by forest communities with a participation of the species of the genera such as: Pinus: P. armandii, P. banksiana, $P$. mugo, $P$. nigra, $P$. sylvestris and $P$. wallichiana. These species were introduced in order to increase the stabilization of the bottom. The tree stands selected for the research are 40 to 45 years old now. Their average height is from $6.0 \mathrm{~m}$ (P. mugo) to $19.9 \mathrm{~m}$ (P. sylvestris), and the average breast height is from $34.0 \mathrm{~cm}(P$. mugo $)$ to $105.0 \mathrm{~cm}$ (P. sylvestris) (Tab. 1). The tree stands grow in the shallow soils of cambisol type (Mochnacký 2001; Kebel and Koštálik 2011). The average annual air temperature over the examined area remains at the level of $+8.4^{\circ} \mathrm{C}$, and the lowest temperatures are in January $\left(-3.4^{\circ} \mathrm{C}\right)$. The average annual volume of precipitation is $643 \mathrm{~mm}$ and comes in June.

Table 1. Characteristic of examined stands

\begin{tabular}{|c|c|c|c|c|c|}
\hline \multicolumn{2}{|c|}{ Species } & \multirow{2}{*}{$\begin{array}{l}\text { Code } \\
\text { P. arm }\end{array}$} & 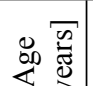 & $\begin{array}{c}\text { Average } \\
\text { height }\end{array}$ & $\begin{array}{c}\text { Average } \\
\text { dbh }\end{array}$ \\
\hline $\begin{array}{l}\text { Pinus } \\
\text { armandii }\end{array}$ & $\begin{array}{l}\text { Chinese } \\
\text { White Pine }\end{array}$ & & \multirow{6}{*}{$\begin{array}{l}\text { in } \\
q \\
q\end{array}$} & 12.5 & 64.5 \\
\hline $\begin{array}{l}\text { Pinus } \\
\text { banksiana }\end{array}$ & Jack Pine & P. ban & & 11.0 & 48.5 \\
\hline $\begin{array}{l}\text { Pinus } \\
\text { mugo }\end{array}$ & $\begin{array}{l}\text { Mountain } \\
\text { Pine }\end{array}$ & P. mug & & 6.0 & 34.0 \\
\hline Pinus nigra & $\begin{array}{l}\text { European } \\
\text { Black Pine }\end{array}$ & P. nig & & 18.0 & 72.5 \\
\hline $\begin{array}{l}\text { Pinus } \\
\text { sylvestris }\end{array}$ & Scots Pine & P. syl & & 19.9 & 105.0 \\
\hline $\begin{array}{l}\text { Pinus } \\
\text { wallichiana }\end{array}$ & Blue Pine & P. wal & & 18.0 & 64.0 \\
\hline
\end{tabular}




\section{Sampling and analysis}

5 trees, each of 6 species of Pinus (P. armandii, P. banksiana, P. mugo, P. nigra, P. sylvestris i P. wallichiana), were earmarked for the study (Tab. 1). Directly under the crowns of the trees, soil samples were taken for physical and chemical analysis from a depth of $0-20 \mathrm{~cm}, 20-40 \mathrm{~cm}$ and $40-60 \mathrm{~cm}$. The samples were dried at a temperature of $65^{\circ} \mathrm{C}$, grinded in the mortar and sieved through the sieve $(1 \mathrm{~mm})$. In the soil, the organic matter content was marked by using the method of roasting in a muffle furnace at a temperature of $550^{\circ} \mathrm{C}$ and $\mathrm{pH}$ in a water solution in a weight proportion $(1: 2.5)$ by a potentiometer method. From each tree, samples of needles from the seventh whorl of weight $10-20 \mathrm{~g}$ were taken for the tests, separating the 1 year old needles from the 2 years old needles, as per the recommendations of ICP Manual Forest (Rautio et al. 2010). After their transport to the labo- ratory, the needles were carefully washed in deionized water to remove any particulate matter. From the trunks of the trees, at the breast height $(1.3 \mathrm{~m})$, samples of the external layer of bark were taken (about $10 \mathrm{~g}$ ). The bark and the needles were dried in paper bags at a temperature of $65^{\circ} \mathrm{C}$ and were homogenized in a laboratory grinder (A11 IKA, Germany). The samples had been kept in tightly closed polyethylene bags till the time of analyses. In the samples of bark and needles, the $\mathrm{pH}$ was determined in a water solution in proportion 1:10 by means of the potentiometer method. In order to determine the metallic elements, the soil samples $(1.0 \mathrm{~g})$ and the samples of needles $(0.5 \mathrm{~g})$ and bark $(0.5 \mathrm{~g})$ were mineralized in the solutions of $65 \% \mathrm{HNO}_{3}$ and $30 \% \mathrm{H}_{2} \mathrm{O}_{2}$ in order to obtain clear and colourless solution. The samples with soil were drained. Then all the samples were supplemented with deionized water (Hydrolab, HLP 10, Poland) to a volume of $50 \mathrm{ml}$.

Table 2. The median physicochemical properties of the soil samples ( \pm standard deviation) taken under trees of Pinus species with Kruskal-Wallis test results

\begin{tabular}{|c|c|c|c|c|c|c|c|c|c|c|}
\hline & \multirow{2}{*}{$\begin{array}{l}\text { Depth } \\
{[\mathrm{m}]}\end{array}$} & \multirow{2}{*}{$\begin{array}{c}\text { Pinus } \\
\text { armandii }\end{array}$} & \multirow{2}{*}{$\begin{array}{c}\text { Pinus } \\
\text { banksiana }\end{array}$} & \multirow{2}{*}{$\begin{array}{l}\text { Pinus } \\
\text { mugo }\end{array}$} & \multirow{2}{*}{$\begin{array}{l}\text { Pinus } \\
\text { nigra }\end{array}$} & \multirow{2}{*}{$\begin{array}{c}\text { Pinus } \\
\text { sylvestris }\end{array}$} & \multirow{2}{*}{$\begin{array}{c}\text { Pinus } \\
\text { wallichiana }\end{array}$} & \multicolumn{2}{|c|}{$\begin{array}{c}\text { Kruskal-Wallis } \\
\text { test }\end{array}$} \\
\hline & & & & & & & & & $\mathrm{H}$ & $\mathrm{p}$ \\
\hline \multicolumn{2}{|c|}{$\mathrm{pH}$} & $\begin{array}{l}0.0-0.2 \\
0.2-0.4 \\
0.4-0.6\end{array}$ & $\begin{array}{l}6.4 \pm 0.2 \\
6.2 \pm 0.2 \\
6.0 \pm 0.3\end{array}$ & $\begin{array}{l}6.6 \pm 0.4 \\
5.7 \pm 0.3 \\
5.8 \pm 0.3\end{array}$ & $\begin{array}{l}6.1 \pm 0.3 \\
6.2 \pm 0.2 \\
6.1 \pm 0.2\end{array}$ & $\begin{array}{l}6.1 \pm 0.1 \\
6.2 \pm 0.1 \\
6.1 \pm 0.1\end{array}$ & $\begin{array}{l}6.6 \pm 0.5 \\
6.5 \pm 0.4 \\
6.4 \pm 0.5\end{array}$ & $\begin{array}{l}6.8 \pm 0.1 \\
6.9 \pm 0.2 \\
7.1 \pm 0.2\end{array}$ & $\begin{array}{l}12.6291 \\
15.3873 \\
15.0151\end{array}$ & $\begin{array}{l}0.0271 \\
0.0088 \\
0.0103\end{array}$ \\
\hline$\sum$ & $\partial^{0}$ & $\begin{array}{l}0.0-0.2 \\
0.2-0.4 \\
0.4-0.6\end{array}$ & $\begin{array}{c}12.7 \pm 2.1 \\
11.2 \pm 1.9 \\
8.6 \pm 2.4\end{array}$ & $\begin{array}{c}10.4 \pm 1.2 \\
8.9 \pm 1.8 \\
8.1 \pm 1.5\end{array}$ & $\begin{array}{l}9.3 \pm 2.0 \\
6.4 \pm 1.7 \\
5.4 \pm 1.1\end{array}$ & $\begin{array}{c}11.6 \pm 1.4 \\
10.4 \pm 2.0 \\
9.7 \pm 1.9\end{array}$ & $\begin{array}{l}9.5 \pm 1.0 \\
8.2 \pm 0.8 \\
7.5 \pm 1.1\end{array}$ & $\begin{array}{l}8.5 \pm 2.9 \\
8.1 \pm 1.5 \\
7.6 \pm 1.0\end{array}$ & $\begin{array}{l}16.4966 \\
16.5201 \\
16.4873\end{array}$ & $\begin{array}{l}0.0056 \\
0.0054 \\
0.0059\end{array}$ \\
\hline$\sum^{\Xi}$ & & $\begin{array}{l}0.0-0.2 \\
0.2-0.4 \\
0.4-0.6\end{array}$ & $\begin{array}{c}554.6 \pm 12.3 \\
549.5 \pm 10.5 \\
571.0 \pm 9.2\end{array}$ & $\begin{array}{l}587.2 \pm 56.3 \\
634.0 \pm 24.3 \\
716.4 \pm 20.4\end{array}$ & $\begin{array}{l}564.9 \pm 19.6 \\
604.1 \pm 16.3 \\
586.0 \pm 21.7\end{array}$ & $\begin{array}{c}616.4 \pm 9.9 \\
599.0 \pm 10.6 \\
604.5 \pm 14.1\end{array}$ & $\begin{array}{l}500.1 \pm 36.9 \\
574.4 \pm 27.3 \\
508.3 \pm 20.6\end{array}$ & $\begin{array}{l}640.3 \pm 15.3 \\
614.6 \pm 22.0 \\
634.0 \pm 18.2\end{array}$ & $\begin{array}{l}16.4966 \\
16.0507 \\
16.1579\end{array}$ & $\begin{array}{l}0.0056 \\
0.0067 \\
0.0064\end{array}$ \\
\hline i. & & $\begin{array}{l}0.0-0.2 \\
0.2-0.4 \\
0.4-0.6\end{array}$ & $\begin{array}{c}35030 \pm 1037 \\
35225 \pm 842 \\
36940 \pm 916\end{array}$ & $\begin{array}{l}41835 \pm 1931 \\
43780 \pm 1412 \\
45945 \pm 1532\end{array}$ & $\begin{array}{l}30385 \pm 557 \\
30180 \pm 773 \\
30285 \pm 841\end{array}$ & $\begin{array}{l}33900 \pm 1842 \\
37345 \pm 1439 \\
36040 \pm 1682\end{array}$ & $\begin{array}{c}31305 \pm 1450 \\
31820 \pm 1172 \\
36675 \pm 774\end{array}$ & $\begin{array}{c}31535 \pm 2447 \\
31820 \pm 1176 \\
31970 \pm 873\end{array}$ & $\begin{array}{l}16.5789 \\
16.1579 \\
13.9357\end{array}$ & $\begin{array}{l}0.0054 \\
0.0064 \\
0.0160\end{array}$ \\
\hline$\vec{~}$ & $\stackrel{00}{=}$ & $\begin{array}{l}0.0-0.2 \\
0.2-0.4 \\
0.4-0.6\end{array}$ & $\begin{array}{l}32.3 \pm 0.9 \\
31.0 \pm 1.0 \\
32.6 \pm 0.8\end{array}$ & $\begin{array}{l}34.5 \pm 2.5 \\
33.3 \pm 1.8 \\
38.7 \pm 1.2\end{array}$ & $\begin{array}{l}32.3 \pm 0.8 \\
32.5 \pm 1.1 \\
33.2 \pm 0.9\end{array}$ & $\begin{array}{l}30.1 \pm 1.5 \\
32.0 \pm 2.0 \\
32.8 \pm 1.7\end{array}$ & $\begin{array}{l}35.5 \pm 1.6 \\
33.3 \pm 1.2 \\
35.8 \pm 1.0\end{array}$ & $\begin{array}{l}69.7 \pm 5.9 \\
71.7 \pm 4.5 \\
81.9 \pm 4.7\end{array}$ & $\begin{array}{l}15.8725 \\
13.6422 \\
15.9500\end{array}$ & $\begin{array}{l}0.0072 \\
0.0180 \\
0.0070\end{array}$ \\
\hline $\bar{z}$ & & $\begin{array}{l}0.0-0.2 \\
0.2-0.4 \\
0.4-0.6\end{array}$ & $\begin{array}{l}35.2 \pm 4.5 \\
29.2 \pm 4.3 \\
35.7 \pm 3.2\end{array}$ & $\begin{array}{l}42.7 \pm 4.4 \\
65.6 \pm 2.8 \\
71.6 \pm 3.0\end{array}$ & $\begin{array}{l}52.7 \pm 3.3 \\
52.1 \pm 2.7 \\
54.4 \pm 2.1\end{array}$ & $\begin{array}{l}58.3 \pm 2.5 \\
55.5 \pm 2.9 \\
57.9 \pm 3.0\end{array}$ & $\begin{array}{l}42.5 \pm 6.5 \\
60.2 \pm 2.4 \\
64.3 \pm 2.1\end{array}$ & $\begin{array}{l}48.7 \pm 3.9 \\
43.5 \pm 3.6 \\
52.2 \pm 1.9\end{array}$ & $\begin{array}{l}16.2515 \\
15.7765 \\
16.1579\end{array}$ & $\begin{array}{l}0.0062 \\
0.0075 \\
0.0064\end{array}$ \\
\hline సี & & $\begin{array}{l}0.0-0.2 \\
0.2-0.4 \\
0.4-0.6\end{array}$ & $\begin{array}{l}84.8 \pm 6.4 \\
71.4 \pm 5.3 \\
72.7 \pm 2.7\end{array}$ & $\begin{array}{l}74.5 \pm 7.2 \\
67.3 \pm 4.2 \\
84.1 \pm 3.3\end{array}$ & $\begin{array}{l}85.4 \pm 4.5 \\
76.8 \pm 5.0 \\
77.1 \pm 3.8\end{array}$ & $\begin{array}{l}86.4 \pm 2.5 \\
85.2 \pm 3.5 \\
88.3 \pm 2.8\end{array}$ & $\begin{array}{l}73.6 \pm 6.7 \\
77.3 \pm 5.5 \\
63.2 \pm 3.1\end{array}$ & $\begin{array}{l}88.3 \pm 7.8 \\
70.3 \pm 7.2 \\
76.7 \pm 6.4\end{array}$ & $\begin{array}{l}15.7368 \\
16.0809 \\
16.2515\end{array}$ & $\begin{array}{l}0.0076 \\
0.0066 \\
0.0062\end{array}$ \\
\hline 己 & & $\begin{array}{l}0.0-0.2 \\
0.2-0.4 \\
0.4-0.6\end{array}$ & $\begin{array}{l}1.7 \pm 0.7 \\
1.5 \pm 0.3 \\
1.7 \pm 0.2\end{array}$ & $\begin{array}{l}0.7 \pm 0.4 \\
1.3 \pm 0.1 \\
1.1 \pm 0.1\end{array}$ & $\begin{array}{l}1.7 \pm 0.7 \\
0.9 \pm 0.3 \\
1.9 \pm 0.2\end{array}$ & $\begin{array}{l}0.4 \pm 0.1 \\
0.5 \pm 0.1 \\
0.3 \pm 0.2\end{array}$ & $\begin{array}{l}0.5 \pm 0.6 \\
1.0 \pm 0.5 \\
0.7 \pm 0.3\end{array}$ & $\begin{array}{l}1.3 \pm 0.6 \\
0.4 \pm 0.6 \\
1.3 \pm 0.2\end{array}$ & $\begin{array}{r}9.7185 \\
7.7262 \\
11.2922\end{array}$ & $\begin{array}{l}0.0836 \\
0.1720 \\
0.0459\end{array}$ \\
\hline
\end{tabular}

Note: the bold p-values are statistically significant. 
The $\mathrm{Zn}, \mathrm{Cu}, \mathrm{Ni}, \mathrm{Mn}, \mathrm{Fe}$ and $\mathrm{Cd}$ content was determined by the method of absorption atomic spectrometry using the Aanalyst 300 instrument (Perkin Elmer, USA). The tests were carried out following the original standards of Merck (KGaA,1g/1000ml). The metals were determined with the following wave lengths: $213.9 \mathrm{~mm} \mathrm{Zn}, 324.8 \mathrm{Cu}$, $232.0 \mathrm{Ni}, 279.5 \mathrm{Mn}, 248.3 \mathrm{Fe}$ and $228.8 \mathrm{Cd}$. All the analyses were performed in three replicates.
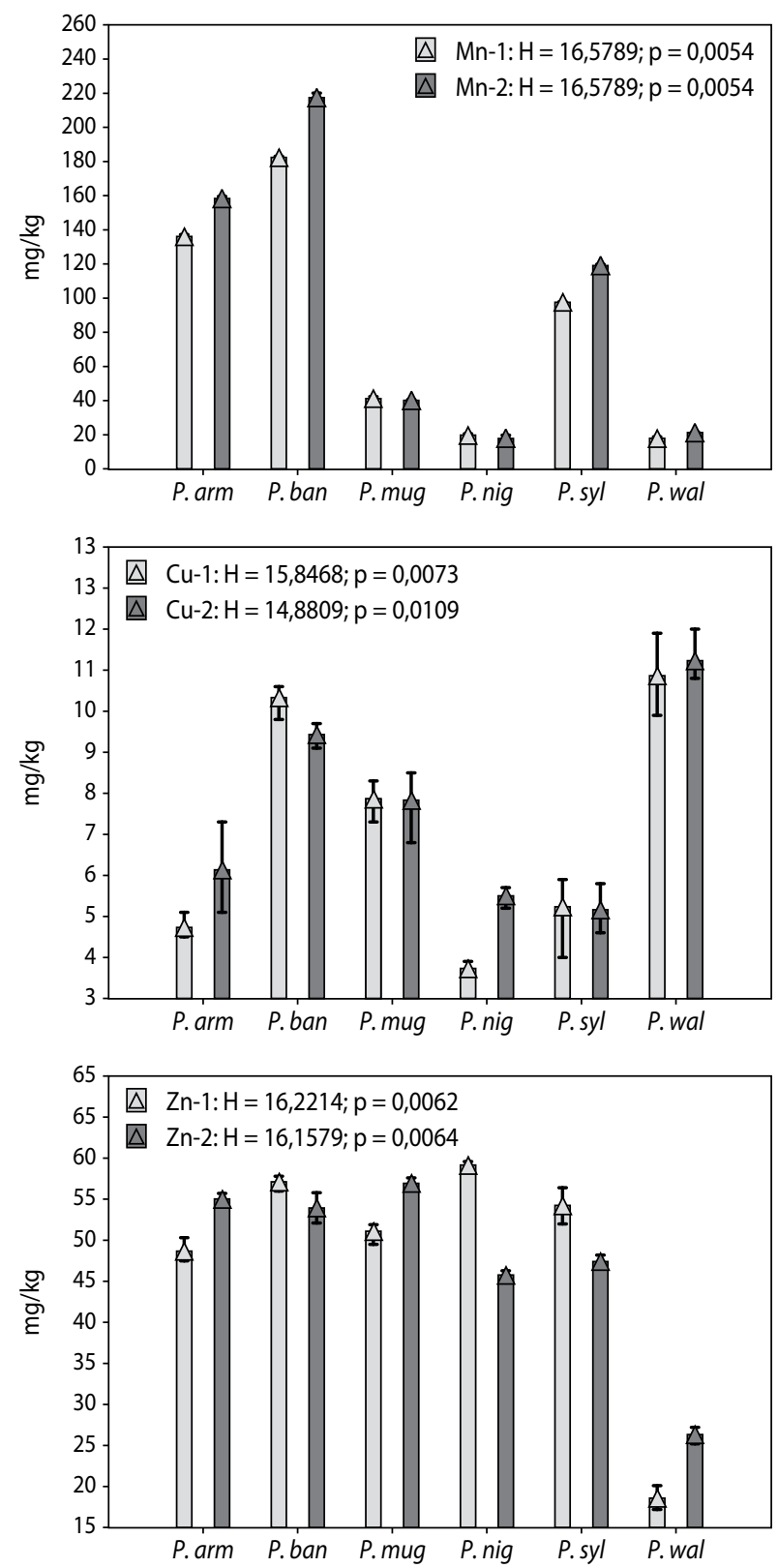

\section{Statistical analysis}

Distribution of physical and chemical data related to the soil, needles and bark was measured by means of application Shapiro Wilk test. The statistical validity between $\mathrm{pH}$ and the heavy metals content in the soil, needles and bark of the tested species of Pinus was established on the basis of a non-parametric Kruskall Wallis test (Tab. 2, 4; Fig. 1). To identify the factors that
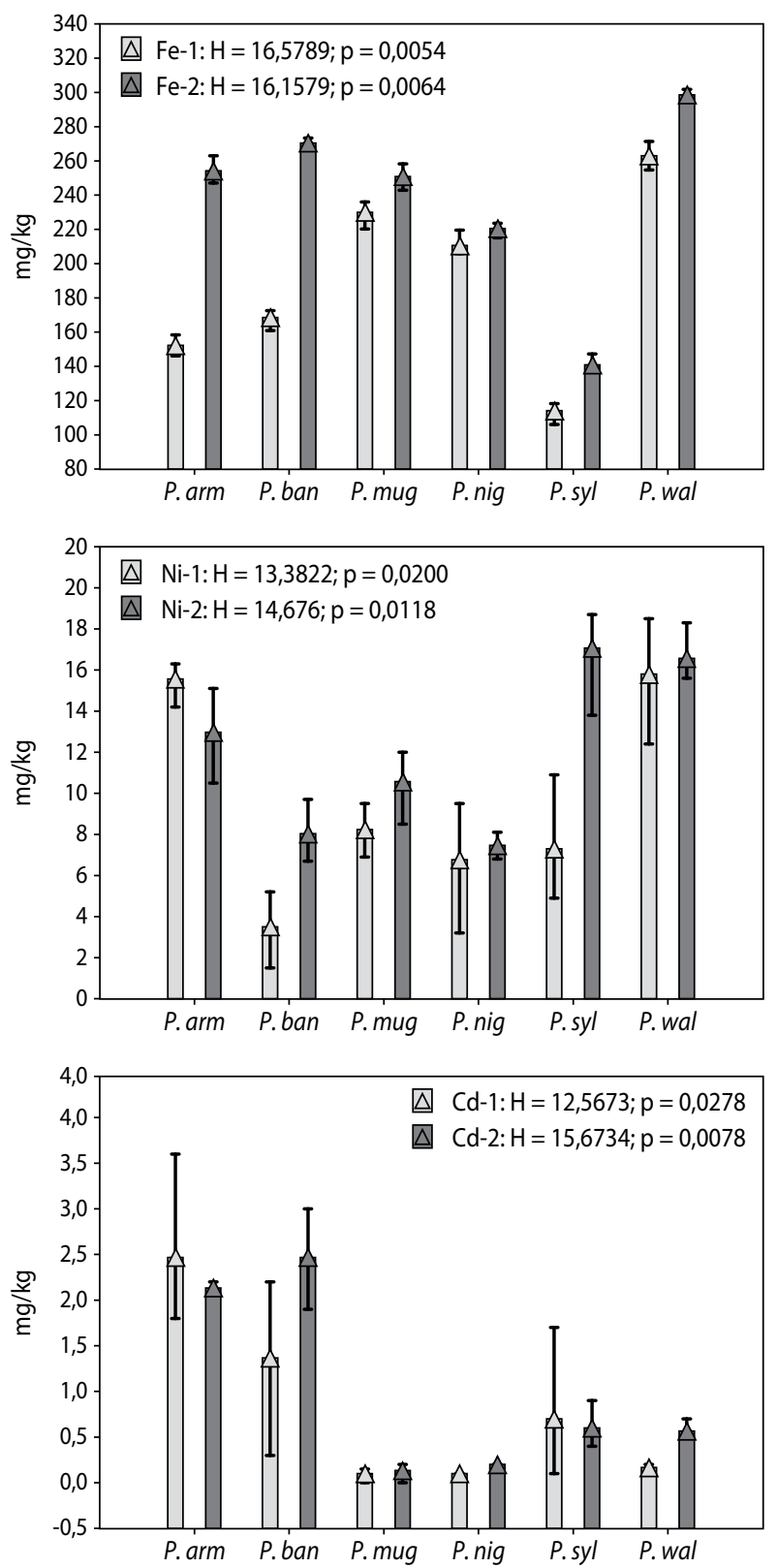

Figure 1. The contents of $\mathrm{Cu}, \mathrm{Ni}, \mathrm{Zn}$ and $\mathrm{Cd}$ in the 1-year and 2-years needles of Pinus species with the Kruskal-Wallis test results (triangle - median values, moustache - minimum and maximum values) 
have an impact on the chemical composition of the bark of the species of Pinus, the method of Principal Components Analysis was applied (PCA). All calculations and charts were prepared in Statistica 7.1 software. In order to provide quality control of the obtained results, an analysis of the certified reference material of the plants was made (CRM 060). The obtained results were within the limits of the error $\pm 3 \%$.

\section{Results}

\section{Physicochemical properties of soil}

The soils under the examined tree stand represented the slightly acidic and neutral reaction, showing little diversity depending on the depth (Tab. 2). An increased soil acidity along with the depth was observed under the tree stand of $P$. banksiana, which had an impact on the increase of bioavailability of manganese and iron for the root system and higher accumulation of $\mathrm{Mn}$ and $\mathrm{Fe}$ in the needles of that species (Fig. 1).

The organic matter content was diversified depending on the species from under which the soil samples were taken, as well as on the depth (Tab. 2). The highest content of the organic matter was discovered in the surface layers of the soil $(0.0-0.2 \mathrm{~m})$, from $8.5 \%$ under the tree stand of $P$. wallchiana to $12.7 \%$ under the crowns of $P$. armandii. In all the research stations, a decrease of organic matter along with the depth was discovered. The lowest content in the layer $0.4-0.6 \mathrm{~m}$ was found in the research stations of $P$. mugo (5.4\%), and the highest under the tree stands of $P$. nigra $(9.7 \%)$.

The content of heavy metals in the soil under the tree stands of Pinus was diverse depending on the species and depth of the layer. In the surface layer $(0.0-0.2 \mathrm{~m})$, the concentration of manganese remained at the level from $500.1 \mathrm{mg} / \mathrm{kg}$ ( $P$. sylvestris) to $640.3 \mathrm{mg} / \mathrm{kg}$ (P. wallchiana), and in the layer of $0.4-0.6 \mathrm{~m}$, from $508.3 \mathrm{mg} / \mathrm{kg}$ (P. sylvestris) to $716.4 \mathrm{mg} / \mathrm{kg}$ (P. banksiana) (Tab. 2). In the tested samples of soils, the lowest content of Fe was discovered under the tree stand of $P$. mugo, and the highest at the tree stands of $P$. banksiana. Under the tree stand of $P$. banksiana, an increase of $\mathrm{Mn}$ and $\mathrm{Fe}$ was observed in the deeper layers of the soil. In case of copper, the highest concentration was discovered in stations under the tree stand of $P$. wallchiana (from $69.7 \mathrm{mg} / \mathrm{kg}$ to $81.9 \mathrm{mg} / \mathrm{kg}$ ), and the lowest in soil under $P$. nigra $(30.1-32.8 \mathrm{mg} / \mathrm{kg})$. The content of zinc in the surface layers of the soil remained at $73.6 \mathrm{mg} / \mathrm{kg}$ under the tree stand of P. sylvestris to $88.3 \mathrm{mg} / \mathrm{kg}$ at the tree stands of $P$. wallchiana. In the layer of $0.4-0.6 \mathrm{~m}$, the concentration of $\mathrm{Zn}$ remained at a similar level as in the layer $0.0-0.2 \mathrm{~m}$ and was from $63.2 \mathrm{mg} / \mathrm{kg}$ (P. sylvestris) to $88.3 \mathrm{mg} / \mathrm{kg}$ ( $P$. nigra). The lowest concentrations of $\mathrm{Cd}$ were discovered under the tree stand $P$. nigra $(0.3-0.5 \mathrm{mg} / \mathrm{kg})$, and the highest concentration was discovered in the case of $P$. armandii $(1.5-1.7 \mathrm{mg} / \mathrm{kg}$ ).

The Kruskal-Wallis test proved statistically significant differences in physical and chemical properties of the soils under the examined species of Pinus except for concentration of cadmium in the layers of the soil 0.0-0.2 and 0.2-0.4 m (Tab. 2).

\section{Physicochemical properties of Pinus species}

The needles of the examined species Pinus were characterized by diversity of $\mathrm{pH}$, but both 1-year old and 2-years old needles represented a strongly acidic reaction. The highest level of acidity was characteristic in the needles of P. banksiana (pH: 4.00-4.18) and P. armandii (pH: 4.00-4.32), and the lowest in the needles of P. sylvestris (pH: 5.25-5.32) (Fig. 2). In majority of the examined species, a slightly higher acidity was represented by 1 year old needles and 2 years old needles except for $P$. wallchiana; in this case, a reverse relation was observed.

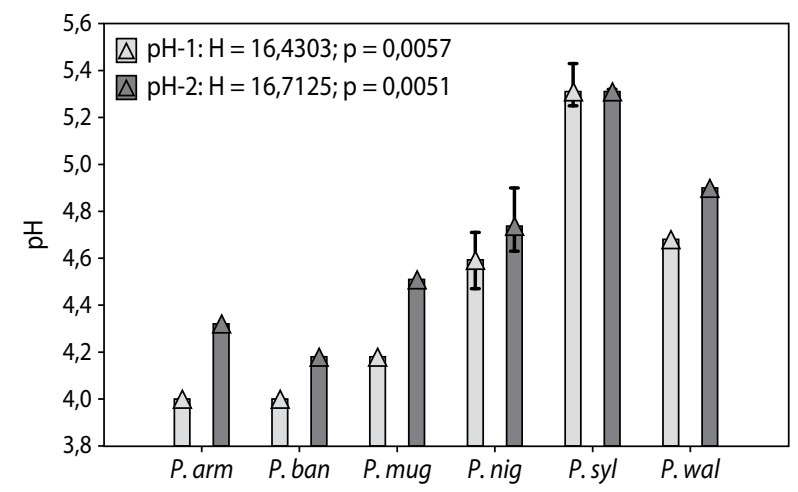

Figure 2. $\mathrm{pH}$ of needles of Pinus species depending on the age of needles with the Kruskal-Wallis test results (trianglemedian values, moustache - minimum and maximum values)

The content of metals in the needles was diversified depending on a species and the age of the needles. 
In most cases, a higher metal content was found in the 2 years old needles, except for $\mathrm{Cu}$ and $\mathrm{Zn}$ (P. banksiana), and $\mathrm{Zn}$ ( $P$. nigra), where higher concentration was discovered in 1 year old needles. The highest concentration of $\mathrm{Fe}$ was characteristic for the needles of P. wallchiana (1-year old - $263.1 \mathrm{mg} / \mathrm{kg}$, 2-years old $-298.6 \mathrm{mg} / \mathrm{kg}$ ), and the lowest content was found in the case of $P$. sylvestris (respectively $114.1 \mathrm{mg} / \mathrm{kg}$ and $140.9 \mathrm{mg} / \mathrm{kg}$ ). The highest concentration of manganese was found in the needles of $P$. banksiana (respectively $182.4 \mathrm{mg} / \mathrm{kg}$ and $217.7 \mathrm{mg} / \mathrm{kg}$ ), and the lowest in the needles of $P$. wallchiana $(17.8 \mathrm{mg} / \mathrm{kg}$ and $21.3 \mathrm{mg} / \mathrm{kg}$ ) (Fig. 1, Tab. 3). The content of zinc in the examined samples were characteristic of the species and remained at the level $18.6-26.3 \mathrm{mg} / \mathrm{kg}$ in $P$. wallchiana, $48.7-55.0 \mathrm{mg} / \mathrm{kg}$ in $P$. armandii, $51.1-56.9 \mathrm{mg} / \mathrm{kg}$ in P. mugo, $47.4-54.2 \mathrm{mg} / \mathrm{kgin}$. sylvestris, $45.8-59.2 \mathrm{mg} / \mathrm{kg}$ in P. nigra and $53.9-57.1 \mathrm{mg} / \mathrm{kg}$ in P. banksiana (Fig. 1, Tab. 3). The highest concentration of copper was discovered in the needles of $P$. wallchiana $(10.9-11.2 \mathrm{mg} / \mathrm{kg}$ ), and the lowest in P. nigra (3.7-5.5 mg/kg). Nickel was accumulated in the highest volume in the needles of P. wallchiana $(15.8-16.6 \mathrm{mg} / \mathrm{kg})$, and the lowest in the needles of $P$. banksiana $(3.5-8.0 \mathrm{mg} / \mathrm{kg})$. In the case of cadmium, the highest concentration was discovered in the needles of $P$. armandii $(2.5 \mathrm{mg} / \mathrm{kg})$, and the lowest in the needles of $P$. mugo $(0.1 \mathrm{mg} / \mathrm{kg}$ ), (Fig. 1, Tab. 3). The examined needles accumulated heavy metals in the volume changing in the decreasing sequences:
- P. armandii: $\mathrm{Fe}>\mathrm{Mn}>\mathrm{Zn}>\mathrm{Ni}>\mathrm{Cu}>\mathrm{Cd}, P$. banksiana: $\mathrm{Fe}>\mathrm{Mn}>\mathrm{Zn}>\mathrm{Cu}>\mathrm{Ni}>\mathrm{Cd}$,

- P. mugo: $\mathrm{Fe}>\mathrm{Zn}>\mathrm{Mn}>\mathrm{Ni}>\mathrm{Cu}>\mathrm{Cd}$, . nigra: $\mathrm{Fe}>\mathrm{Zn}>\mathrm{Mn}>\mathrm{Ni}>\mathrm{Cu}>\mathrm{Cd}$,

- P. sylvestris: $\mathrm{Fe}>\mathrm{Mn}>\mathrm{Zn}>\mathrm{Ni}>\mathrm{Cu}>\mathrm{Cd}$ i $P$. wallchiana: $\mathrm{Fe}>\mathrm{Zn}>\mathrm{Mn}>\mathrm{Ni}>\mathrm{Cu}>\mathrm{Cd}$.

The Pinus species under consideration were grouped by the application of Ward method on the basis of similarity in accumulation of heavy metals in needles and two main groups were separated. In group I - P. armandii, $P$. banksiana and $P$. sylvestris were found, and in the second group - P. mugo, P. nigra and P. wallchiana were found (Fig. 3).

\section{Physicochemical properties of bark}

All samples of the examined bark had a strongly acidic reaction, having values of $\mathrm{pH}$ from 3.7 ( $P$. sylvestris) to 4.9 (P. armandii) (Tab. 4). The heavy content of metals in the bark of the species Pinus was strictly dependent on the surface of the bark under consideration. Concentrations of Mn remained at the level from $13.0 \mathrm{mg} / \mathrm{kg}$ (P. nigra) to $67.3 \mathrm{mg} / \mathrm{kg}$ (P. armandii), and the iron content had the values from $253.8 \mathrm{mg} / \mathrm{kg}$ ( $P$. wallchiana) to $1122.7 \mathrm{mg} / \mathrm{kg}$ (P. armandii). Zinc constituted substantially lower quantities in the bark having the values from $42.7 \mathrm{mg} / \mathrm{kg}$ (P. sylvestris) to $118.7 \mathrm{mg} / \mathrm{kg}$ (P. mugo). Nickel concentrations remained at the level from $41.4 \mathrm{mg} / \mathrm{kg}$ (P. wallchiana) to $90.6 \mathrm{mg} / \mathrm{kg}$ (P. sylvestris), and copper from $6.9 \mathrm{mg} / \mathrm{kg}(P$. mugo and $P . n i-$

Table 3. The average \pm standard deviation of heavy metals concentration $(\mathrm{mg} / \mathrm{kg})$ in the 1-year and 2-years needles of Pinus species

\begin{tabular}{|c|l|c|c|c|c|c|c|}
\hline \multicolumn{1}{|c|}{ Species } & \multicolumn{1}{|c|}{ Age of needles } & $\mathrm{Mn}$ & $\mathrm{Fe}$ & $\mathrm{Cu}$ & $\mathrm{Ni}$ & $\mathrm{Zn}$ & $\mathrm{Cd}$ \\
\hline \multirow{3}{*}{ Pinus armandii } & 1-year of needles & $136.1 \pm 1.5$ & $152.3 \pm 6.2$ & $4.7 \pm 0.3$ & $15.6 \pm 1.2$ & $48.7 \pm 1.5$ & $2.5 \pm 0.9$ \\
\cline { 2 - 7 } & 2-years of needles & $158.4 \pm 2.0$ & $254.2 \pm 8.1$ & $6.1 \pm 1.1$ & $13.0 \pm 2.3$ & $55.0 \pm 0.7$ & $2.1 \pm 0.1$ \\
\hline \multirow{3}{*}{ Pinus banksiana } & 1-year of needles & $182.4 \pm 1.2$ & $168.5 \pm 6.6$ & $10.3 \pm 0.5$ & $3.5 \pm 1.9$ & $57.1 \pm 0.9$ & $1.4 \pm 0.9$ \\
\cline { 2 - 7 } & 2-years of needles & $217.5 \pm 3.0$ & $270.5 \pm 2.9$ & $9.4 \pm 0.3$ & $8.0 \pm 1.5$ & $53.9 \pm 1.8$ & $2.5 \pm 0.6$ \\
\hline \multirow{3}{*}{ Pinus mugo } & 1-year of needles & $41.4 \pm 1.8$ & $229.9 \pm 8.6$ & $7.9 \pm 0.5$ & $8.2 \pm 1.3$ & $51.1 \pm 1.4$ & $0.1 \pm 0.1$ \\
\cline { 2 - 8 } & 2-years of needles & $40.1 \pm 0.5$ & $250.8 \pm 7.1$ & $7.8 \pm 0.9$ & $10.6 \pm 1.8$ & $56.9 \pm 0.6$ & $0.1 \pm 0.1$ \\
\hline \multirow{3}{*}{ Pinus nigra } & 1-year of needles & $19.8 \pm 0.7$ & $210.6 \pm 7.8$ & $3.7 \pm 0.2$ & $6.8 \pm 3.2$ & $59.2 \pm 0.4$ & $0.1 \pm 0.0$ \\
\cline { 2 - 8 } & 2-years of needles & $17.8 \pm 2.2$ & $220.7 \pm 4.7$ & $5.5 \pm 0.3$ & $7.5 \pm 0.7$ & $45.8 \pm 0.5$ & $0.2 \pm 0.0$ \\
\hline \multirow{2}{*}{ Pinus sylvestris } & 1-year of needles & $97.6 \pm 0.5$ & $114.1 \pm 6.9$ & $5.2 \pm 1.1$ & $7.3 \pm 3.2$ & $54.2 \pm 2.2$ & $0.7 \pm 0.6$ \\
\cline { 2 - 7 } & 2-years of needles & $119.1 \pm 1.0$ & $140.9 \pm 5.6$ & $5.2 \pm 0.6$ & $17.1 \pm 2.8$ & $47.4 \pm 0.8$ & $0.6 \pm 0.3$ \\
\hline & 1-year of needles & $17.9 \pm 1.5$ & $263.1 \pm 8.4$ & $10.9 \pm 1.0$ & $15.8 \pm 3.1$ & $18.6 \pm 1.5$ & $0.2 \pm 0.1$ \\
\cline { 2 - 7 } & 2-years of needles & $21.3 \pm 0.3$ & $298.6 \pm 3.6$ & $11.2 \pm 0.7$ & $16.6 \pm 1.5$ & $26.3 \pm 1.0$ & $0.6 \pm 0.1$ \\
\hline
\end{tabular}




\section{DE GRUYTER}

\section{OPEN}

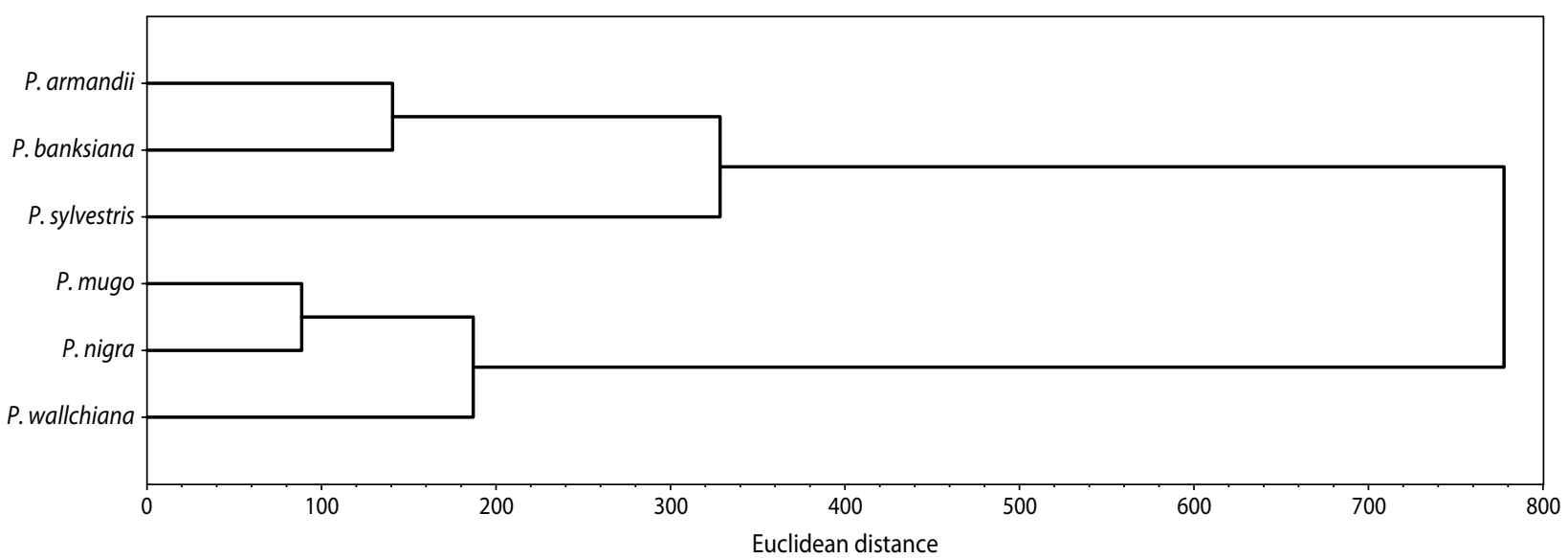

Figure 3. Similarity of the investigated Pinus species in relation to the contents of $\mathrm{Mn}, \mathrm{Fe}, \mathrm{Cu}, \mathrm{Ni}, \mathrm{Zn}$ and $\mathrm{Cd}$ in needles (Euclidean distance, Ward's clustering method).

Table 4. The median of $\mathrm{pH}$ and heavy metals concentration $(\mathrm{mg} / \mathrm{kg})$ in bark of Pinus species with Kruskal-Wallis test results

\begin{tabular}{|c|c|c|c|c|c|c|c|c|c|}
\hline & & \multirow{2}{*}{$\begin{array}{c}\text { Pinus } \\
\text { armandii }\end{array}$} & \multirow{2}{*}{$\begin{array}{c}\text { Pinus } \\
\text { banksiana }\end{array}$} & \multirow{2}{*}{$\begin{array}{l}\text { Pinus } \\
\text { mugo }\end{array}$} & \multirow{2}{*}{$\begin{array}{l}\text { Pinus } \\
\text { nigra }\end{array}$} & \multirow{2}{*}{$\begin{array}{c}\text { Pinus } \\
\text { sylvestris }\end{array}$} & \multirow{2}{*}{$\begin{array}{c}\text { Pinus } \\
\text { wallichiana }\end{array}$} & \multicolumn{2}{|c|}{ Kruskal-Wallis test } \\
\hline & & & & & & & & $\mathrm{H}$ & $\mathrm{p}$ \\
\hline $\mathrm{pH}$ & & $4.9 \pm 0.2$ & $3.9 \pm 0.5$ & $4.4 \pm 0.6$ & $4.5 \pm 0.2$ & $3.7 \pm 0.3$ & $4.2 \pm 0.3$ & 16.875 & 0.0047 \\
\hline $\mathrm{Mn}$ & \multirow{6}{*}{$\mathrm{mg} / \mathrm{kg}$} & $67.3 \pm 6$ & $27.0 \pm 2$ & $35.3 \pm 13$ & $13.0 \pm 2$ & $31.7 \pm 6$ & $20.3 \pm 2$ & 14.4978 & 0.0127 \\
\hline $\mathrm{Fe}$ & & $1122.7 \pm 6$ & $613.2 \pm 2$ & $792.3 \pm 5$ & $629.2 \pm 2$ & $655.8 \pm 5$ & $253.8 \pm 4$ & 16.5789 & 0.0054 \\
\hline $\mathrm{Cu}$ & & $10.1 \pm 1$ & $8.6 \pm 0.5$ & $6.9 \pm 0.7$ & $6.9 \pm 0.5$ & $7.3 \pm 0.2$ & $7.7 \pm 1.4$ & 11.3569 & 0.0447 \\
\hline $\mathrm{Ni}$ & & $48.2 \pm 1$ & $42.7 \pm 6$ & $43.6 \pm 7$ & $80.5 \pm 2$ & $90.6 \pm 2$ & $41.4 \pm 4$ & 15.8304 & 0.0073 \\
\hline $\mathrm{Zn}$ & & $66.5 \pm 2$ & $57.4 \pm 1$ & $118.7 \pm 1$ & $76.0 \pm 2$ & $42.7 \pm 1$ & $59.3 \pm 1$ & 16.5789 & 0.0054 \\
\hline $\mathrm{Cd}$ & & $2.5 \pm 0.9$ & $0.8 \pm 0.5$ & $2.4 \pm 0.8$ & $1.2 \pm 0.7$ & $2.1 \pm 1.6$ & $1.9 \pm 0.9$ & 6.9527 & 0.2242 \\
\hline
\end{tabular}

Note: the gray p-values are statistically significant.

gra) to $10.1 \mathrm{mg} / \mathrm{kg}$ (P. armandii). From among the examined metals, cadmium was found in the lowest quantities, having the values from $0.8 \mathrm{mg} / \mathrm{kg}$ (P. banksiana) to $2.5 \mathrm{mg} / \mathrm{kg}$ ( $P$. armandii). The results obtained from the research showed the statistically significant differences in the concentration of $\mathrm{Mn}, \mathrm{Fe}, \mathrm{Cu}, \mathrm{Ni}$ and $\mathrm{Zn}$ in the bark of the species Pinus (Tab. 4).

In order to identify factors determining the chemical composition of the bark, Principal Components Analysis (PCA) was applied. $\mathrm{pH}$ and concentrations of $\mathrm{Mn}, \mathrm{Fe}, \mathrm{Cu}, \mathrm{Ni}, \mathrm{Zn}$ and $\mathrm{Cd}$ in the bark were used for calculation, depending on the species. 2 independent factors explaining $73 \%$ of variance of chemical composition of the examined bark samples were used as the main components (Tab. 5). For interpretation of data, only such values of the factor loadings were used,
Table 5. Results of principal component analysis $(P C A)$ the heavy metals content in bark of Pinus species, $\mathrm{n}=90$

\begin{tabular}{|l|c|c|}
\hline \multicolumn{1}{|c|}{ Parameter } & $P C 1$ & $P C 2$ \\
\hline $\mathrm{pH}$ & -0.78 & 0.02 \\
\hline $\mathrm{Mn}$ & -0.88 & -0.22 \\
\hline $\mathrm{Fe}$ & -0.89 & -0.01 \\
\hline $\mathrm{Cu}$ & -0.63 & -0.64 \\
\hline $\mathrm{Ni}$ & -0.35 & 0.94 \\
\hline $\mathrm{Zn}$ & -0.35 & 0.89 \\
\hline $\mathrm{Cd}$ & -0.48 & 0.16 \\
\hline Eigenvalues & 2.97 & 2,16 \\
\hline \multirow{2}{*}{ Explained variance [\%] } & 42 & 31 \\
\cline { 2 - 4 } & & \\
\hline
\end{tabular}

Note: in gray factor loading higher than 0.7 are highlighted. 
which were higher than 0.7 . Factor 1 explained $42 \%$ of the chemical composition and grouped $\mathrm{pH}, \mathrm{Mn}$ and $\mathrm{Fe}$ characterized by high, negative factor loadings. Factor 2 explained $31 \%$ changeability of chemical composition of the bark and was indirectly proportional to the content of $\mathrm{Ni}$ and $\mathrm{Zn}$.

\section{Discussion}

\section{Physicochemical properties of soil}

The main deciding factor for availability of heavy metals for plants is the reaction of soil. The solubility of heavy metals is low in the neutral and alkaline reactions, and increases with the lowering of $\mathrm{pH}$ value (Gworek 2006), thereby increasing the bioaccumulation factors in plants (Gębski 1998). Increase of mobility of $\mathrm{Zn}, \mathrm{Mn}$ and $\mathrm{Cd}$ is most effective with $\mathrm{pH}=6.0, \mathrm{Fe}$ at $\mathrm{pH}=4.0$, while $\mathrm{Ni}$ and $\mathrm{Cu}$ at $\mathrm{pH}=5.5$. Manganese, however, is characterized by increased solubility in alkaline environment as well (Alloway 1995).

Dead plant remains which constitute an important link in the circulation of matter and energy flow constitute the source of organic matter. Its quantity and quality influences the characteristics of the soil and nutrition for the plants (Astel et al. 2009; Polláková et al. 2015). Increased organic matter content in the surface layers of soil is a result of systematic influx of organic deposition that takes place throughout the year (Astel et al. 2009); its distribution depends on the species and qualitative properties of the tree stand (Jonczak et al. 2015). The largest quantities of organic matter were found in the soil under the tree stands of $P$. armandii and $P$. nigra, which result most probably from a slower speed of decomposition of their organic remains.

According to Kabata-Pendias and Pendias (1999), the occurrence of trace elements in the soil depends on their content in the parent rock and on the character of the soil creation processes. Atmospheric dust deposition, which is a carrier of many heavy metals, especially at the areas under influence of anthropogenic factors, had vital impact on concentration of trace elements in the surface layer of the soil (Tainio et al. 2010; Parzych and Jonczak 2014; Rapport 2016). Metals deposited in the surface layer of soil are bound by the constant phase of the soil, absorbed by organisms and undergo migration along with water filtering in. The quantity of bio- available forms of heavy metals is strictly dependent on the soil reaction and organic matter content (Parzych and Jonczak 2013). Increase of $\mathrm{Mn}$ and $\mathrm{Fe}$ content in the soil along with the depth under the three stand of P. banksiana, is an effect of increase of acidity of the soil in the layers $0.2-0.4 \mathrm{~m}$ and $0.4-0.6 \mathrm{~m}$ in relation to the layer $0.0-0.2 \mathrm{~m}$. Acidification causes washing out of soluble forms of manganese and iron to the deeper layers of the soil. Similar phenomenon was observed under the tree stand of P. sylvestris at the area of Słowiński National Park (northern Poland), (Parzych and Jonczak 2013).

\section{Physicochemical properties of Pinus species}

Strong acidic reaction of the needles of the species of Pinus is characteristic for the coniferous tree stands, and in the case of $P$. sylvestris, it reaches the values of $\mathrm{pH}=3.0-3.2$ (Świercz 2006). The influence of external factors, such as alkaline emission, substantially lowers the acidity of needles of $P$. sylvestris $(\mathrm{pH}=4.8-5.3)$ (Świercz 2003).

Concentrations of trace elements in the needles of the examined species of Pinus were relatively low, except for nickel ( $P$. armandii, P. sylvestris, P. wallchiana) and cadmium, (P. armandii, P. banksiana), which showed increased levels of these metals. Small content of metals in the needles was a result of limited availability of particular metals from the soil due to $\mathrm{pH}$. From among the examined metals, iron dominated in all the samples (Fig. 1), not exceeding however, the acceptable level (<375 mg/kg) (Kabata-Pendias and Pendias 1999). Iron content in the samples of needles $P$. nigra from Košice were slightly higher than the ones which were found at the territory of Poland at the Słowiński National Park (SPN) (Parzych and Sobisz 2012), which reflects the impact of anthropogenic factors. Low content of $\mathrm{Mn}$ in the needles of $P$. wallchiana resulted from the negative reaction of the soil (Tab. 1), where manganese was available for plants to a small extent. Physiological demand of most plants for $\mathrm{Mn}$ is usually from 10 to $25 \mathrm{mg} / \mathrm{kg}$. Toxic levels were found in none of the examined samples of the needles ( $>500 \mathrm{mg} / \mathrm{kg}$ ) (Kabata-Pendias and Pendias 1999). Substantially higher Mn content was found in the needles of $P$. sylvestris and P. nigra at the area of SPN due to strongly acidic reaction of soils increasing the availability of manganese compounds for the root system. Concentrations of zinc in the needles 
of the examined species of Pinus were close to the results obtained in the case of $P$. sylvestris and $P$. nigra at the area of SPN (Parzych and Sobisz 2012). The average zinc content in the over-ground parts of the plants, which were not under the impact of pollution, usually remains at the level of $10-70 \mathrm{mg} / \mathrm{kg}$. To cover the physiological needs of most plants, sufficient concentration of zinc in the leaves is within $15-30 \mathrm{mg} / \mathrm{kg}$, and copper at the level of $4-5 \mathrm{mg} / \mathrm{kg}$. However, the average $\mathrm{Cu}$ content in over ground parts of the plants is usually from 5 to $20 \mathrm{mg} / \mathrm{kg}$ (Kabata-Pendias and Pendias 1999) and is highly diversified depending on the part of the plant, species and genus. However, Cadmium as a toxic metal, is accumulated by plants in a passive way (Baran and Jasiewicz 2009). Concentrations of Cd in the needles of the species Pinus represent little contamination of soils under the examined tree stands. The accumulative properties of the needles in relation to $\mathrm{Mn}, \mathrm{Fe}$, $\mathrm{Cu}, \mathrm{Ni}, \mathrm{Zn}$ and $\mathrm{Cd}$ indicate mutual similarities between some species of Pinus. In group I, P. armandii, P. banksiana and $P$. sylvestris are found, which have needles characterized by a relatively high iron, manganese and zinc content $(\mathrm{Fe}>\mathrm{Mn}>\mathrm{Zn})$ and $P$. mugo, $P$. nigra and $P$. wallchiana, characterized by a high concentration of iron, zinc and manganese $(\mathrm{Fe}>\mathrm{Zn}>\mathrm{Mn})$. Differences in accumulation of $\mathrm{Zn}$ and $\mathrm{Mn}$ in the needles of $P$. sylvestris and $P$. nigra was also found during the research done by Parzych and Sobisz (2012).

\section{Physicochemical properties of bark}

The tissue covering the plants is a very important and exceptionally sensitive bio-indicator of pollution of the natural environment. The test results confirmed that $\mathrm{pH}$ of the bark of trees is characteristic for the species and has the values of $\mathrm{pH}$ from 3.0 to 5.5 (Marmor and Randlane 2007). The reaction of the bark depends also on the age, health status of the trees and the properties of the substratum on which it grows (Chrzan 2013). The test results in the literature indicate that the bark of $P$. sylvestris shows a strongly acidic reaction with $\mathrm{pH}$ within 3.1-3.3 (Marko-Worłowska et al. 2010) and 3.1-3.9 (Chrzan 2013). Moreover, the bark of coniferous trees is characterized by higher acidity than the bark of leafy trees (Chrzan et al. 2010). The bark of the trees, depending on the structure and porosity, arrests the dust and aerosols in the quantities proportional to their surface (Chrzan 2013), sometimes showing even higher con- centrations of a given metal than in the soil (Kuang et al. 2007). The obtained results of the research indicate that the highest quantities of $\mathrm{Mn}, \mathrm{Fe}, \mathrm{Cu}$ and $\mathrm{Cd}$ were accumulated by the bark of $P$. armandii, nickel by the bark of $P$. sylvestris, and $\mathrm{Cu}$ by the bark of $P$. mugo. The research done by Rykowska and Wasiak (2009) proves that the accumulation of heavy metals in the bark of the trees strongly depends on the species and on the impact of anthropogenic factors, which is also confirmed by the research concerning $P$. armandii, $P$. banksiana, P. mugo, P. nigra, P. sylvestris and P. wallichiana from Košice. As per Chrzan et al. (2010), the coniferous trees accumulate metals in higher quantities than the leafy species. The bark of Pinus sylvestris can accumulate from 32.4 to $143.3 \mathrm{mg} / \mathrm{kg}$ Zn (Chrzan 2013), and the bark of Robinia pseudoacacia from $1.4 \mathrm{mg} / \mathrm{kg}$ to $26.9 \mathrm{mg} / \mathrm{kg} \mathrm{Zn} \mathrm{(Kraszkiewicz} \mathrm{2010).}$

The results of the factor analysis clearly diversify the sources of origin of heavy metals in the bark of the examined species Pinus. Factor 1 indicates the origin of iron and manganese for the same local sources of pollution, such as iron processing, machine and textile industry functioning in the area of Košice. Factor 2 comprises nickel and zinc, which are most often sourced from the atmospheric precipitation originating from industry, communication and transport (Rapport 2016).

\section{Conclusions}

The examined soils were abundant at an average level in the basic micro components, contained small quantities of cadmium, and their availability for trees depended on soil reaction. From among the tested species, the needles of $P$. banksiana were characterized by the highest level of acidity that had an impact on the soil reaction under the tree stand and on the higher accumulation of $\mathrm{Fe}$ and $\mathrm{Mn}$ in the needles.

In most cases, higher levels of content of those metals was determined in the 2 years old needles, except for $\mathrm{Cu}$ and $\mathrm{Zn}$ (P. banksiana) as well as $\mathrm{Zn}$ (P. nigra), in which case, higher concentration of metals in 1 year old needles was determined. This indicates a greater sensitivity of the needles of these species to $\mathrm{Cu}$ and $\mathrm{Zn}$. From among the examined elements, Mn was accumulated in the largest volume in the needles of $P$. banksiana, Fe and $\mathrm{Cu}$ in the needles of $P$. wallchiana, $\mathrm{Ni}$ in the needles 
of $P$. sylvestris, $\mathrm{Zn}$ in the needles of $P$. nigra, and $\mathrm{Cd}$ in the needles of $P$. armandii. Chemical analyses of the needles of $P$. armandii, $P$. sylvestris and $P$. wallchiana indicate a small pollution of the tested area with nickel and the needles of P. armandii and P. banksiana show increased content of cadmium. The examined bark samples indicated strongly acidic reaction. The highest quantities of $\mathrm{Mn}, \mathrm{Fe}, \mathrm{Cu}$ and $\mathrm{Cd}$ were accumulated by the bark of $P$. armandii, Ni by the bark of $P$. sylvestris, and $\mathrm{Cu}$ by the bark of P. mugo.

\section{References}

Alloway B.J. 1995. Soil processes and the behavior of metals. In: Heavy metals in soils (ed.: B.J. Alloway). 2nd ed. Blackie, Glasgow, Great Britain.

Arsova A. 1999. Adaptality of Pinus nigra Arn. depending on soil pH. Bulgarian Journal of Plant Physiology, $25(1 / 2), 16-25$.

Astel A., Parzych A., Trojanowski J. 2009. Comparision of litterfall and nutrient return in a Vaccinio uliginosi-Betuletum pubescentis and a Empetro nigriPinetum forest stands in northern Poland. Forest Ecology and Management, 257, 2331-2341.

Augusto L., Ranger J., Binkley D., Rothe A. 2002. Impact of several common tree species of European temperate forests on soil fertility. Annals of Forest Science, 59, 233-253.

Baran A., Jasiewicz C. 2009. Toksyczna zawartość cynku i kadmu w glebie dla różnych gatunków roślin. Ochrona Środowiska i Zasobów Naturalnych, 40, 157-164.

Christensen K.I., Dar G.H. 1997. A morphometric analysis of spontaneous and artificial hybrids of Pinus mugo-sylvestris (Pinaceae). Nordic Journal of Botany, 17, 77-86.

Chrzan A., Marko-Worłowska-Łaciak T. 2010. Contamination of soil land pine bark by heavy metals in Skałki Twardowskiego Landscape Park in Kraków. Proceedings of ECOpole, 4 (1), 115-119.

Chrzan A. 2013. Zawartość wybranych metali ciężkich $\mathrm{w}$ glebie i korze sosny. Proceedings of ECOpole 7 (2), 547-552.

Espelta J.M., Retana J., Habrouk A. 2003. An economic and ecological multi-criteria evaluation of reforestation methods to recover burned Pinus nigra for- ests in NE Spain. Forest Ecology and Management, 180, 185-198.

Gębski M. 1998. Czynniki glebowe oraz nawozowe wpływające na przyswajanie metali ciężkich przez rośliny. Postępy Nauk Rolniczych, 5, 3-16.

Gworek B. 2006. Glin w środowisku przyrodniczym a jego toksyczność. Ochrona Środowiska i Zasobów Naturalnych, 29, 27-38.

Jonczak J., Parzych A., Sobisz Z. 2015. Decomposition of four leaf litters in headwater riparian forest. Baltic Forestry, 21 (1), 133-143.

Kabata-Pendias A., Pendias H. 1999. Biogeochemia pierwiastków śladowych. PWN, Warszawa, Polska.

Kebel P., Koštálik J. 2011. Geological and geomorphological characteristics of the area of Botanical Garden of PJŠU in Košice and the use of these data in botanical practice. Thaiszia - Journal of Botany, 21, 153-159.

Kraszkiewicz A. 2010. Zawartość wybranych metali ciężkich w drewnie Robinii akacjowej. Problemy Inżynierii Rolniczej, 2, 131-136.

Kuang Y.W., Zhou G.Y., Wen D., Liu S.Z. 2007. Heavy metals in bark of Pinus massoniana (Lamb.) as an indicator of atmospheric deposition near a smeltery at Qujiang, China. Environmental Science Pollution Research International, 14 (4), 270-275.

Lamppu J., Huttunen S. 2002. Relations between Scott pine needle element concentrations and decreased needle longevity along pollution gradients. Environmental Pollution, 122, 119-126.

Marko-Worłowska M., Wątor G., Kozik R., Łaciak T. 2010. Zawartość związków zakwaszających i metali ciężkich w korze martwicowej sosny pospolitej (Pinus sylvestris L.) oraz $\mathrm{w}$ glebie małych lasów w Skawinie i Krakowie. Proceedings ECOpole, 4 (2), 459-463.

Marmor L., Randlane T. 2007. Effects of road traffic on bark pH and epiphytic lichens in Tallinn. Folia Cryptogamica Estonica, 43, 23-37.

Migaszewski Z.M. 1997. Chemistry of Scots pine (Pinus sylvestris L.) needles in the Cross Mountains region (south-central Poland). Wiadomości Botaniczne, 42 (3/4), 79-91.

Mochnacký S. 2001. Botanická záhrada Univerzity P.J. Šafárika v Košiciach. ES UPJŚ Košice, Slovakia. 
Parzych A., Jonczak J. 2013. Content of heavy metals in needles of Scots pine (Pinus sylvestris L.) in selected of pine forest in the Słowiński National Park. Archives of Environmental Protection, 1 (39), 41-51.

Parzych A., Jonczak J. 2014. Pine needles (Pinus sylvestris L.) as bioindicators in the assessment of urban environmental contamination with heavy metals. Journal of Ecological Engineering, 15 (3), 29-38.

Parzych A., Sobisz Z. 2012. The macro- and microelemental content of Pinus sylvestris L. and Pinus nigra J.F. Arn. needles in Cladonio-Pinetum habitat of the Słowiński National Park. Forest Research Papers, 73 (4), 295-303.

Polláková N., Šimanský V., Ložek O., Hanáčková E., Candráková E. 2015. The changes of nutrient and risk elements of top soil layers under canopy of different tree species and grassland in Arboretum Mlyňany, Slovakia. Folia Oecologica, 42 (1), 29-34.

Pusz W., Zwijacz-Kozica T., Kita W. 2015. Ocena zdrowotności igieł kosodrzewiny (Pinus mugo) w wybranych lokalizacjach Tatrzańskiego Parku Narodowego. Sylwan, 159 (5), 411-418.

Rapport 2016. Air pollution in the Slovak Republic. Ministry of Environment of the Slovak Republic. Slovak Hydrometeorological Institute, Bratyslava.

Rautio P., Fürst A., Stefan K., Raitio H., Bartels U. 2010. Sampling and analysis of needles and leaves. 19 pp. Manual Part XII. In: Manual and methods and criteria for harmonized sampling, assessment, monitoring and analysis of the effects to air pollu- tion on forests. UNECE ICP Forest Programme Coordinating Centre, Hamburg.

Reyes O., Casal M. 2006. Can smoke affect the germination of Pinus sylvestris, $P$. nigra, $P$. uncinata and P. pinaster? Forest Ecology and Management, 234 Suppl., 184. doi:10.1016/j.foreco.2006.303

Rykowska I., Wasiak W. 2009. Dystrybucja rtęci i metali ciężkich w korze drzew liściastych jako wskaźnik skażenia środowiska. Gospodarka Odpadami Komunalnymi, 273-282.

Świercz A. 2003. Metallic elements' content in soil, needles and bark of pine trees after the reduction of alcalic immission. Reginalny Monitoring Środowiska Przyrodniczego, 4, 107-113.

Świercz A. 2006. Suitability of pine bark to evaluate pollution caused by cement-lime dust. Journal of Forest Science, 52, 93-98.

Tainio M., Kekkonen J., Nahorski Z. 2010. Impact of airborne particulate master on human heath an assessment framework to estimate exposure and adverse heath effect in Poland. Archives of Environmental Protection, 36 (1), 95-115.

Wójcik J., Krzaklewski W. 2009. Zalesienia jako metoda rekultywacji terenów bezglebowych w PGE KWB „Turów”. Bezpieczeństwo Pracy i Ochrona Środowiska w Górnictwie, 6, 29-37.

Yilmaz S., Zengin M. 2003. Monitoring environmental pollution in Erzurum by chemical analysis of Scott pine (Pinus sylvestris L.) needles. Environmental International, 29, 1041-1047. 